\title{
Pengaruh Konsentrasi Daun Belimbing Wuluh (Averhoa Bilimbi L.) dan Lama Penyimpanan terhadap Kualitas Fisik Telur Puyuh
}

\section{The Effect of Wuluh Star Fruit (Averhoa Bilimbi L.) Leaves Concentration and Storage Duration to Physical Quality of Quail Eggs}

\author{
Sari Wiji Utami ${ }^{1)}$, Silfiatus Saadah ${ }^{1)}$, Fatimatuz Zuhro ${ }^{2)}$ \\ ${ }^{1}$ Program Studi Agribisnis, Politeknik Negeri Banyuwangi, Jl. Raya Jember Km. 13 Labanasem Kabat, \\ Banyuwangi, 68461 \\ ${ }^{2}$ Program Studi Pendidikan Biologi, FPMIPA, IKIP PGRI Jember \\ E-mail: sariwijiutamilpoliwangi.ac.id
}

\begin{abstract}
The purpose of this research was to analize physical quality of quail eggs which has soaked with wuluh star fruit leaves extract and has storaged for some weeks. This research used 108 quail eggs, 0 day old. This research used a Completely Randomized Design with 6 leaves extract concentrastion treatments $(0 \%, 10 \%, 15 \%, 20 \%, 25 \%$, and $30 \%)$ and 6 durations of storage treatments $(0,1,2,3,4$, and 5 weeks) with three replication. The data were analyzed by ANOVA 5\% and continued with Duncan test. The result showed that leaves extract concentrastion treatments gave significant effect to egg weight, eggshell weight, egg white weight, yolk score, albumin pH, Haugh Unit (HU), and the shell thick of quail eggs. The interaction treatment gave significant effect to eggshell wheight, albumin pH, and the shell thick of quail eggs.
\end{abstract}

Keywords- leaves extract, physical quality, storage duration, quail eggs, wuluh star fruit.

\section{PENDAhUluan}

Telur puyuh merupakan bagian dari hasil produk hewan unggas puyuh. Telur puyuh banyak digemari oleh sebagian besar masyarakat karena memiliki ukuran yang kecil dan kerabangnya yang bercorak unik, serta dapat dimanfaatkan sebagai bahan olahan pangan yang bernilai gizi tinggi dan kandungan gizinya tidak kalah dengan produk telur hewan unggas lainnya, seperti telur itik, telur ayam ras dan ayam buras. Telur puyuh memiliki kandungan 47,4\% albumin (putih telur), 31,9\% yolk (kuning telur), serta $20,7 \%$ kerabang dan selaput tipis [1] Sari, 2009. Ketebalan kerabang telur puyuh sekitar 0,197 mm dan ketebalan membran atau selaput tipis
$0,063 \mathrm{~mm}$, bobot telur puyuh rata-rata 10 gram atau $8 \%$ dari bobot tubuh puyuh betina.

[2] Djaelani (2016) menyatakan bahwa faktor lama penyimpanan akan menyebabkan penurunan kualitas telur dan merubah kondisi fisik telur. Penurunan kualitas telur yang terjadi mengarah pada kerusakan telur seperti berkurangnya bobot telur karena terjadi penguapan kadar air melalui pori-pori kerabang, dan sampai penurunan tingkat kekentalan (viskositas) isi telur, sehingga terjadi pengenceran. Kerusakan telur dapat diketahui dengan ciri-ciri kerusakan isi telur yang terdiri dari putih telur (albumin) dan kuning telur (yolk) berubah menjadi cair atau tercampur, muncul bau yang tidak sedap, bila digoyang akan berbunyi, retak atau pecah pada kulit luarnya, dan jika dimasukkan dalam air akan 
mengapung atau melayang di permukaan air. Telur yang sudah mengalami penguapan air atau banyak kehilangan $\mathrm{CO}_{2}$ akan melayang dan terapung serta telah mengalami penurunan kualitas, sedangkan telur yang jika dimasukkan dalam air dapat tenggelam menunjukkan bahwa telur kualitasnya masih bagus.

Penurunan kualitas telur selama masa simpan dapat dipengaruhi oleh mikroba yang mengontaminasi telur yang menyebabkan masa simpannya tidak akan lama [3] Ismawati, 2011. Pertumbuhan mikroba perusak tersebut yang didukung dengan kondisi suhu, kelembaban, dan pengolahan yang kurang baik menyebabkan masa simpan telur semakin berkurang, sehingga perlu penanganan untuk mempertahankan kualitas telur dengan cara pengawetan [4] Nugraha et al., 2013. [5] Idris (2014) menyatakan bahwa cara pengawetan dengan penutupan pori- pori kulit telur dengan bahan pengawet dapat dilakukan dengan memanfaatkan zat tannin yang terdapat pada tanaman belimbing wuluh (Averrhoa bilimbi L.).

Kadar senyawa aktif tertinggi pada tanaman belimbing wuluh terdapat pada bagian daun. Perbandingan kadar tannin pada bagian daun belimbing wuluh menunjukkan bahwa daun muda mengandung kadar tannin $1,60 \%$ dan daun tua 1,28\% [6] Mukhlisoh, 2010. Belimbing wuluh mengandung zat tannin dan flavonoid terutama pada buah dan daunnya [7] Herlih (1993). Tannin merupakan senyawa antimikroba yang dapat menghambat pertumbuhan mikroba dengan cara mengganggu metabolisme mikroba yang merugikan, mengganggu kebutuhan membran sel mikroba sehingga menyebabkan keluarnya komponen sel mikroba dan mengakibatkan terhambatnya sintetis protein sel mikroba. Zat tannin pada ekstrak daun belimbing wuluh akan meminimalisir terjadinya denaturasi protein dan hilangnya karbondioksida pada telur puyuh dapat dicegah [8] Karmila, et al., (2008).

Daun belimbing wuluh dipilih dalam penelitian karena kandungan tinggi tannin yang dapat digunakan sebagai bahan utama dalam pengawetan telur puyuh. Pengaruh kombinasi antara perlakuan perendaman telur puyuh dalam ekstrak daun belimbing wuluh dan lama penyimpanannya akan diteliti lebih lanjut pada penelitian ini.

\section{METODE PENELITIAN}

Penelitian ini dilakukan pada bulan Juni sampai November 2017 di Laboratorium Teknologi Pengolahan Hasil Ternak Politeknik Negeri Banyuwangi. Peralatan yang digunakan, antara lain; nampan, pisau, timbangan digital, kantong plastik, gelas ukur, panci, jangka sorong, cawan petri, sendok, toples, yolk color fun, dan blender. Sedangkan bahan-bahan yang digunakan antara lain; daun belimbing wuluh, telur puyuh, air, kertas label, kertas $\mathrm{pH}$, dan kertas tissue.

Penelitian ini menggunakan telur puyuh yang berumur nol (0) hari sebanyak 108 butir yang diperoleh dari salah satu peternakan burung puyuh di Kecamatan Arjasa Kabupaten Jember. Prosedur penelitian dimulai dengan membuat ekstrak daun belimbing wuluh, dengan tahapan yang terdiri dari; daun belimbing wuluh yang telah dipisahkan dari ranting dicincang kemudian dijemur sampai kering, daun belimbing wuluh yang sudah kering dihaluskan menggunakan blender sampai halus kemudian disaring, daun belimbing wuluh yang sudah halus selanjutnya direbus selama 5 menit pada suhu $70^{\circ} \mathrm{C}$, dengan beberapa konsentrasi $(\mathrm{K})$, yaitu; konsentrasi $0 \%$ (K0; sebagai kontrol), konsentrasi $10 \%$ (K1; 10 gr daun belimbing wuluh kering), konsentrasi $15 \%$ (K2; 15 gr daun belimbing wuluh kering), konsentrasi $20 \%$ (K3; 20 gr daun belimbing wuluh kering), konsentrasi 25\% (K4; 25 gr daun belimbing wuluh kering), dan konsentrasi 30\% (K5; 30 gr daun belimbing wuluh kering). Perebusan dilakukan masing-masing dengan $200 \mathrm{ml}$ air.

Selanjutnya telur direndam dalam ekstrak belimbing wuluh dengan beberapa perlakuan waktu perendaman, yaitu; 0 minggu (P0), 1 minggu (P1), 2 minggu (P2), 3 minggu (P3), 4 minggu (P4), dan 5 minggu (P5). Beberapa parameter kualitas fisik telur yang diamati pada penelitian ini, antara lain; bobot telur, bobot kerabang telur, tebal kerabang telur, tinggi putih telur, bobot kuning dan putih telur, nilai Haugh Unit (HU), skor warna kuning telur, serta $\mathrm{pH}$ putih dan kuning telur.

Penelitian ini menggunakan Rancangan Acak Lengkap (RAL) faktorial dengan pola 6x6 yaitu 6 perlakuan konsentrasi, 6 perlakuan masa penyimpanan, dan ulangan sebanyak 3 kali. Faktor pertama adalah perlakuan konsentrasi ekstrak daun belimbing wuluh dan faktor kedua adalah lama penyimpanan telur puyuh. Data hasil penelitian dianalisis dengan menggunakan analisis Anova yang dilanjutkan dengan uji Duncan dengan taraf kepercayaan 95\% menggunakan program IBMSPSS versi 2.2.

\section{HASIL DAN PEMBAHASAN}

\section{A. Bobot Telur Puyuh}

Hasil analisis anova menunjukkan bahwa perlakuan konsentrasi ekstrak daun belimbing wuluh dan lama penyimpanan berpengaruh nyata terhadap bobot telur puyuh. Tetapi, kombinasi perlakuan keduanya tidak berpengaruh nyata terhadap bobot telur. Hasil uji lanjut Duncan dari kedua faktor tunggal perlakuan dapat dilihat pada Tabel 1. sebagai berikut. 
Sari Wiji Utami, Silfiatus Saadah, Fatimatuz Zuhro. Pengaruh Konsentrasi Daun Belimbing Wuluh (Averhoa Bilimbi L.) dan Lama Penyimpanan terhadap Kualitas Fisik Telur Puyuh

TABEL 1.

HASIL UJi DUNCAN FAKTOR TUNGGAL PERLAKUAN

\begin{tabular}{|c|c|c|c|c|}
\hline \multirow{3}{*}{$\begin{array}{l}\mathrm{N} \\
\mathrm{o}\end{array}$} & \multicolumn{4}{|c|}{ Jenis Perlakuan } \\
\hline & \multicolumn{2}{|c|}{$\begin{array}{c}\text { Konsentrasi Ekstrak Daun } \\
\text { Belimbing (K) }\end{array}$} & \multicolumn{2}{|c|}{$\begin{array}{c}\text { Lama Penyimpanan } \\
(\mathrm{P})\end{array}$} \\
\hline & $\begin{array}{c}\text { Konsentrasi } \\
(\%)\end{array}$ & $\begin{array}{l}\text { Rerata } \\
\text { Bobot } \\
\text { Telur } \\
\end{array}$ & $\begin{array}{l}\text { Waktu } \\
\text { (minggu) }\end{array}$ & $\begin{array}{l}\text { Rerata } \\
\text { Bobot } \\
\text { Telur } \\
\end{array}$ \\
\hline 1. & $0 \%$ & $11.77 \mathbf{b}$ & 0 & $11.45 \mathbf{b}$ \\
\hline 2. & $10 \%$ & $11.07 \mathbf{a b}$ & 1 & $11.03 \mathbf{a b}$ \\
\hline 3. & $15 \%$ & $10.43 \mathbf{a}$ & 2 & $10.93 \mathbf{a b}$ \\
\hline 4. & $20 \%$ & $10.69 \mathbf{a}$ & 3 & $10.74 \mathbf{a b}$ \\
\hline 5. & $25 \%$ & $10.35 \mathbf{a}$ & 4 & $10.25 \mathbf{a}$ \\
\hline 6. & $30 \%$ & $10.47 \mathbf{a}$ & 5 & $10.38 \mathbf{a}$ \\
\hline
\end{tabular}

Keterangan: Angka yang diikuti oleh notasi huruf yang sama menunjukkan hasil berbeda tidak nyata berdasarkan uji Duncan.

Berdasarkan Tabel 1. di atas dapat diketahui bahwa konsentrasi ekstrak daun belimbing wuluh $0 \%$ dan $10 \%$ memiliki pengaruh terbaik terhadap bobot telur burung puyuh. Sedangkan lama penyimpanan dari 0 sampai 3 minggu menunjukkan hasil bobot telur yang lebih tinggi daripada penyimpanan selama 4 dan 5 minggu.

Penurunan bobot telur berjalan lebih cepat mulai pada awal penyimpanan sampai pada minggu pertama dan kemudian melambat pada minggu ke5. Hal ini diduga terjadi karena penguapan air dan gas $\mathrm{CO}_{2}$ berlangsung lebih cepat pada awal penyimpanan. Seiring dengan semakin lamanya waktu penyimpanan persediaan cairan dan gas akan semakin menyusut atau berkurang (Harahap, 2007).

Hasil interaksi kedua faktor tersebut tidak berpengaruh nyata terhadap bobot telur puyuh. Hal tersebut disebabkan karena kandungan zat tannin yang ada di dalam daun belimbing wuluh hanya dapat berfungsi sebagai antimikroba, sehingga tidak dapat menambah berat pada telur puyuh selama penyimpanan.

\section{B. Bobot Kerabang Telur Puyuh}

Kerabang telur merupakan struktur telur yang paling luar. Fungsi dari kerabang telur yaitu mengurangi kerusakan fisik seperti retaknya kerabang dan biologis telur [9] Kurtini, et al., 2011. Hasil analisis anova menunjukkan bahwa perlakuan tunggal dan interaksinya berpengaruh nyata terhadap bobot kerabang telur puyuh.

Berdasarkan hasil analisis data, telur puyuh dengan perlakuan tanpa perendaman/kontrol dan lama penyimpanan 5 minggu (KOP5) memiliki bobot kerabang dengan nilai paling tinggi yaitu $2,55 \mathrm{gr}$, sedangkan nilai rataan terendah terdapat pada perlakuan K5P2 (konsentrasi 30\% dan penyimpanan 5 minggu) dengan nilai 1,10 gr. Sementara itu, interaksi perlakuan konsentrasi 0\% dan lama penyimpanan 5 minggu (K0P5) ternyata menghasilkan nilai bobot kerabang yang tertinggi di antara perlakuan yang lainnya.

Bobot kerabang dan tebal tipisnya kerabang telur dipengaruhi oleh strain ternak, umur induk, pakan, stress dan penyakit pada induk. Semakin tua umur ternak maka semakin tipis kerabang telurnya dan semakin ringan juga bobot kerabang, karena ternak tidak mampu untuk memproduksi kalsium yang cukup untuk memenuhi kebutuhan kalsium dalam pembentukan kerabang telur [10] Yuwanta, 2010.

\section{Bobot Kuning Telur}

Berat kuning telur dipengaruhi oleh perkembangan ovarium, berat badan ternak, umur saat mencapai dewasa kelamin, kualitas dan kuantitas pakan, penyakit, dan lingkungan serta konsumsi pakan [11] Tugiyanti dan Iriyanti, 2012.

Berdasarkan hasil analisis anova menunjukkan bahwa perlakuan konsentrasi ekstrak daun buah belimbing tidak berpengaruh nyata terhadap bobot kuning telur, tetapi lama penyimpanan berpengaruh terhadap bobot kuning telur. Sedangkan interaksi antara 2 perlakuan tidak berpengaruh terhadap bobot kuning telur.

Berdasarkan data nilai rataan bobot kuning telur dapat diketahui bahwa telur puyuh dengan perlakuan tanpa perendaman dengan lama penyimpanan 1 minggu (K0P1) memiliki nilai rataan bobot kuning telur tertinggi yaitu 4,97 gr, sedangkan bobot kuning telur terendah terdapat pada perlakuan konsentrasi $30 \%$ dan lama penyimpanan 5 minggu (K5P5) yaitu 2,76 gr. Hal tersebut diduga karena zat tannin pada daun belimbing wuluh hanya menutup pori-pori kerabang telur. [12] Zita, et al. (2013) menyatakan bahwa genotif, umur dan jumlah kolesterol telur berpengaruh terhadap bobot kuning telur.

Lama penyimpanan berpengaruh nyata terhadap bobot kuning telur puyuh. Tetapi, penyimpanan telur yang terlalu lama akan mengakibatkan menurunnya kualitas interior telur seperti menurunnya kekentalan putih telur, kuning telur, bobot putih dan kuning telur, meningkatnya nilai $\mathrm{pH}$ putih dan $\mathrm{pH}$ kuning telur, tinggi putih telur, dan rendahnya nilai HU [13] Abbas, 1989. Pada penelitian ini, lama penyimpanan yang berpengaruh terbaik bagi bobot kuning telur adalah 1 minggu.

\section{Bobot Putih telur}

Yuwanta (2010) menyatakan bobot putih telur puyuh normal berkisar 4.1-6 g butir. Berdasarkan hasil analisis anova menunjukkan bahwa perlakuan konsentrasi ekstrak daun belimbing wuluh dan lama penyimpanan berpengaruh nyata terhadap bobot telur puyuh, sedangkan interaksi antara keduanya tidak berpengaruh nyata terhadap bobot putih telur.

Berdasarkan nilai rerata bobot putih telur dapat diketahui bahwa telur puyuh dengan perlakuan tanpa perendaman dengan lama penyimpanan 5 minggu 
(K0P5) memiliki nilai rataan tertinggi yaitu $6,92 \mathrm{gr}$, sedangkan bobot putih telur terendah terdapat pada perlakuan konsentrasi perendaman $30 \%$ dengan lama penyimpanan 1 minggu (K5P1) yaitu 4,35 gr. Hasil uji Duncan perlakuan konsentrasi ekstrak daun belimbing wuluh dan lama penyimpanan tersaji pada Tabel 2. sebagai berikut.

TABEL 2

HASIL UJI DUNCAN FAKTOR TUNGGAL PERLAKUAN

\begin{tabular}{|c|c|c|c|c|}
\hline \multirow{3}{*}{ No. } & \multicolumn{4}{|c|}{ Jenis Perlakuan } \\
\hline & \multicolumn{2}{|c|}{$\begin{array}{c}\text { Konsentrasi Ekstrak Daun } \\
\text { Belimbing }\end{array}$} & \multicolumn{2}{|c|}{ Lama Penyimpanan } \\
\hline & $\begin{array}{c}\text { Konsentrasi } \\
(\%)\end{array}$ & $\begin{array}{l}\text { Rerata } \\
\text { Bobot } \\
\text { Putih } \\
\text { Telur }\end{array}$ & $\begin{array}{l}\text { Waktu } \\
\text { (minggu) }\end{array}$ & $\begin{array}{l}\text { Rerata } \\
\text { Bobot } \\
\text { Putih } \\
\text { Telur }\end{array}$ \\
\hline 1. & $0 \%$ & $6.14 \mathbf{b}$ & 0 & $6.19 \mathbf{b}$ \\
\hline 2. & $10 \%$ & $5.52 \mathbf{a}$ & 1 & $5.41 \mathbf{a}$ \\
\hline 3. & $15 \%$ & $5.38 \mathbf{a}$ & 2 & $5.40 \mathbf{a}$ \\
\hline 4. & $20 \%$ & $5.35 \mathbf{a}$ & 3 & $5.26 \mathbf{a}$ \\
\hline 5. & $25 \%$ & $5.16 \mathbf{a}$ & 4 & $5.24 \mathbf{a}$ \\
\hline 6. & $30 \%$ & $5.08 \mathbf{a}$ & 5 & $5.13 \mathbf{a}$ \\
\hline
\end{tabular}
menunjukkan hasil berbeda tidakcnyata berdasarkan uji Duncan.

Berdasarkan Tabel 2. di atas tampak bahwa perlakuan perendaman dalam ekstrak daun belimbing wuluh dan lama penyimpanan berpengaruh negatif terhadap rerata bobot putih telur puyuh. Hal tersebut nampak pada perlakuan kontrol yang justru memiliki rerata bobot putih telur yang lebih besar daripada perlakuan lainnya.

Penurunan nilai bobot telur puyuh disebabkan oleh penguapan gas $\mathrm{CO}_{2}$ dalam telur secara terus menerus, sehingga kualitas telur menurun. Proses penguapan gas $\mathrm{CO}_{2}$ melalui pori-pori kulit albumen menyebabkan perubahan fisik dan kimia, sehingga albumen menjadi berair (encer). Semakin encer putih telur, maka semakin semakin rendah ketinggian putih telur yang berarti kualitasnya semakin menurun [14] Joni, et al., 2017.

\section{E. Skor Warna Kuning Telur}

[15] Juliambarwati, et al. (2012) menyatakan bahwa untuk mengetahui kualitas skor warna kuning telur perlu dilakukan pengukuran dengan menggunakan yolk color fan dengan skala 1-15 dan berwarna kuning pucat hingga kuning jingga tua. Skor warna kuning telur akibat kombinasi perlakuan yang diberikan pada penelitian ini tertera pada Tabel 3. sebagai berikut.
TABEL 3.

SKOR WARNA KUNING TELUR

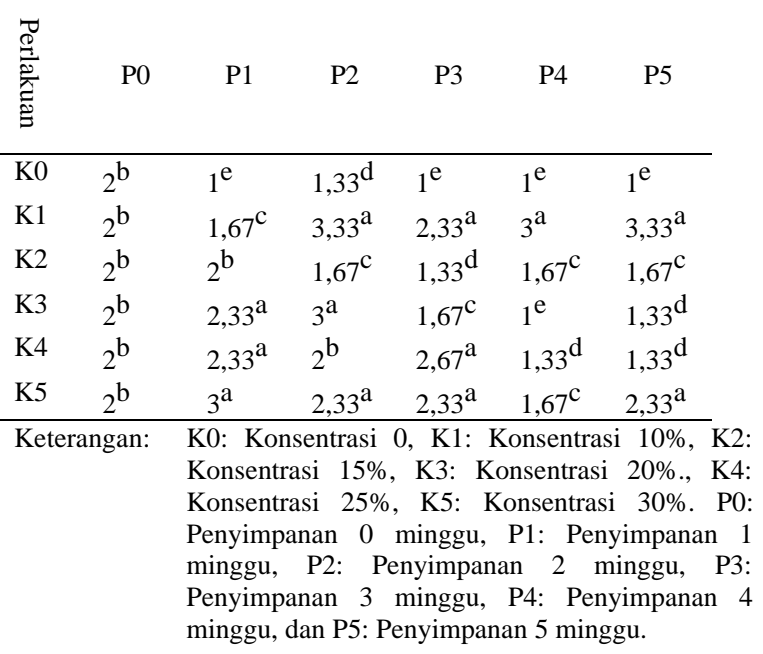

Nilai rataan skor warna kuning telur pada Tabel 3. berada kisaran 1-4, diketahui bahwa telur puyuh pada perlakuan K1P2 dan K1P5 memiliki kesamaan nilai rataan tertinggi yaitu 3,33, sedangkan skor warna kuning telur terendah terdapat pada 4 perlakuan tanpa perendaman dan satu perlakuan dengan perendaman K0P1, K0P3, K0P4, K0P5, dan K3P4 yang memiliki kesamaan skor yaitu 1,00. Adanya perbedaan skor warna kuning telur ini diduga disebabkan oleh perbedaan kemampuan metabolisme dalam mencerna ransum dan perbedaan dalam menyerap pigmen xantophyl dalam ransum yaitu pigmen yang memberi warna pada kuning telur.

Hasil analisis Anova menunjukkan bahwa perlakuan perendaman dengan ekstrak daun belimbing wuluh berpengaruh nyata terhadap skor warna kuning telur. [16] Argo, et al. (2013) menyatakan bahwa skor warna kuning telur salah satunya dipengaruhi oleh kandungan nutrisi pakan dari ransum. Lama penyimpanan juga berpengaruh nyata terhadap skor warna kuning telur. Pada saat penyimpanan telur, akan terjadi perpindahan air dari putih telur ke kuning telur. Skor warna kuning telur akan semakin rendah dengan semakin lamanya penyimpanan telur. Tetapi, pada penelitian ini hal tersebut belum terjadi, karena diduga perpindahan air dari putih telur ke kuning telur belum besar sehingga keadaan kuning telur masih baik dan belum mempengaruhi skor warna kuning telur. Faktor yang berpengaruh terhadap skor warna kuning telur antara lain tingginya produktivitas ternak, dan kandungan pigmen xantophyl dalam ransum [17] Yamamoto, et al., 2007.

\section{F. Tinggi Putih Telur}

Hasil analisis Anova pada parameter tinggi putih telur menunjukkan bahwa perlakuan perendaman dengan ekstrak daun belimbing wuluh tidak 
Sari Wiji Utami, Silfiatus Saadah, Fatimatuz Zuhro. Pengaruh Konsentrasi Daun Belimbing Wuluh (Averhoa Bilimbi L.) dan Lama Penyimpanan terhadap Kualitas Fisik Telur Puyuh

berpengaruh nyata terhadap tinggi putih telur. Tetapi, lama penyimpanan berpengaruh nyata terhadap tinggi putih telur. Hasil uji Duncan pengaruh perlakuan lama penyimpanan terhadap tinggi putih telur tersaji pada Tabel 4 sebagai berikut.

\begin{tabular}{|c|c|c|c|c|}
\hline \multirow{2}{*}{$\begin{array}{c}\text { Lama } \\
\text { Penyimpanan }\end{array}$} & \multirow[b]{2}{*}{$\mathrm{N}$} & \multicolumn{3}{|c|}{ Subset } \\
\hline & & 1 & 2 & 3 \\
\hline 5 minggu & 18 & 1.8894 & & \\
\hline 2 minggu & 18 & 1.9361 & 1.9361 & \\
\hline 1 minggu & 18 & 2.1133 & 2.1133 & 2.1133 \\
\hline 3 minggu & 18 & & 2.2372 & 2.2372 \\
\hline 0 minggu & 18 & & & 2.4006 \\
\hline 4 minggu & 18 & & & 2.4156 \\
\hline Sig. & & .169 & .064 & .072 \\
\hline
\end{tabular}

Berdasarkan Tabel 4. tersebut dapat diketahui bahwa lama penyimpanan telur puyuh selama 0,1 , 3 , dan 4 minggu memberikan pengaruh yang tidak berbeda nyata terhadap tinggi putih telur dan menghasilkan tinggi telur yang lebih besar daripada perlakuan lama penyimpanan lainnya. [18] Hintono (1997) menyatakan bahwa bertambahnya umur telur mengakibatkan putih telur menjadi encer dan akan bercampur dengan kuning telur. Hal ini disebabkan oleh putih telur mengalami kenaikan $\mathrm{pH}$ yang berakibat pada berkurangnya kadar karbondioksida yang akhirnya mengakibatkan serabut-serabut ovomucin rusak dan pecah. Akibatnya bagian cair dari putih telur menjadi encer dan tinggi putih telur mulai berkurang.

\section{G. pH Kuning Telur}

Berdasarkan data penelitian menunjukkan bahwa nilai rataan $\mathrm{pH}$ kuning telur berkisar antara 6-9 dan $\mathrm{pH}$ kuning telur konstan dengan nilai 7 terdapat pada dua perlakuan tanpa perendaman K0P0, K0P3, dan 3 perlakuan dengan perendaman K4P3, K5P0, serta K5P5. [19] Idris (2014) menyatakan bahwa nilai rataan 7 pada $\mathrm{pH}$ kuning telur puyuh yang disimpan pada suhu ruang selama 5 minggu yang direndam dengan konsentrasi ekstrak daun belimbing wuluh disebabkan oleh tannin dalam daun belimbing wuluh menutup pori-pori kerabang telur sehingga penguapan gas karbondioksida sedikit. Sebaliknya, tingginya $\mathrm{pH}$ telur yang disimpan pada suhu ruang selama enam minggu yang tidak diawetkan dengan larutan daun belimbing wuluh (konsentrasi 0\%) disebabkan oleh penguapan gas $\mathrm{CO} 2$ yang banyak.

Hasil analisis Anova menunjukkan bahwa perlakuan perendaman dengan ekstrak daun belimbing wuluh tidak berpengaruh nyata terhadap pH kuning telur. Tetapi, lama penyimpanan berpengaruh nyata terhadap $\mathrm{pH}$ kuning telur. Hasil uji Duncan pengaruh lama penyimpanan terhadap
pH kuning telur puyuh tertera pada Tabel 5. sebagai berikut.

TABEl 5. Uji DUNCAN PENGARUH LAMA PENYIMPANAN TERHADAP PH KUNING TELUR PUYUH

\begin{tabular}{cccc}
\hline Lama & & \multicolumn{2}{c}{ Subset } \\
\cline { 3 - 4 } Penyimpanan & $\mathrm{N}$ & 1 & 2 \\
\hline 0 minggu & 18 & 6.8889 & \\
3 minggu & 18 & 6.9444 & \\
5 minggu & 18 & 7.0556 & \\
2 minggu & 18 & 7.1667 & \\
1 minggu & 18 & 7.2222 & \\
4 minggu & 18 & & .9444 \\
\hline Sig. & & 351 & 1.000 \\
\hline
\end{tabular}

Data penelitian menunjukkan bahwa ada kecenderungan meningkatnya $\mathrm{pH}$ kuning telur seiring bertambahnya lama penyimpanan. Berdasarkan Tabel 5. di atas, lama penyimpanan 4 minggu menghasilkan $\mathrm{pH}$ kuning telur tertinggi di antara perlakuan lainnya. Hal ini sejalan dengan hasil penelitian [20] Djaelani (2016), dimana pada minggu pertama $\mathrm{pH}$ telur berkisar 7 , meningkat menjadi sekitar 8 setelah minggu ke-2, dan $\mathrm{pH}$ meningkat menjadi 8,5 setelah lebih dari 2 minggu waktu penyimpanan. Pada penelitian ini, kombinasi perlakuan tidak memberikan pengaruh yang nyata terhadap $\mathrm{pH}$ kuning telur.

\section{H. $p H$ Putih Telur}

Berdasarkan hasil analisis Anova menunjukkan bahwa terdapat pengaruh perlakuan perendaman, lama penyimpanan, dan interaksinya terhadap $\mathrm{pH}$ putih telur. Data hasil penelitian menunjukkan bahwa semakin lama telur puyuh disimpan, maka $\mathrm{pH}$ putih telurnya semakin meningkat. Tingginya $\mathrm{pH}$ putih telur puyuh selama penyimpanan di suhu ruang selama 5 minggu dengan perlakuan perendaman ekstrak daun belimbing wuluh disebabkan karena zat tannin tidak mampu menutupi kerabang telur sehingga penguapan gas $\mathrm{CO}_{2}$ lebih banyak. Tetapi, penyimpanan telur yang terlalu lama akan mengakibatkan penurunan kualitas internal telur seperti menurunnya kekentalan putih telur, kuning telur, bobot putih dan kuning telur, meningkatnya nilai $\mathrm{pH}$ putih dan $\mathrm{pH}$ kuning telur, tinggi putih telur, dan rendahnya nilai HU [21] Abbas, 1989.

\section{Nilai Haugh Unit (HU) Telur}

Nilai Haugh Unit (HU) merupakan nilai yang menggambarkan keadaan putih telur dalam rangka untuk menentukan kualitas telur. Telur yang berkualitas baik biasanya memiliki nilai HU yang tinggi [22] Hajrawati, et al., 2012. Menurut [23] Kurtini e al (2014), HU telur yang tinggi mencerminkan kondisi telur yang masih segar. Nilai HU lebih dari 72 dikategorikan sebagai telur berkualitas AA, nilai HU 60-72 sebagai telur 
berkualitas A, nilai HU 31-60 sebagai telur berkualitas B dan nilai HU kurang dari 31 dikategorikan sebagai telur berkualitas C [24] USDA, 2007.

Hasil analisis Anova pada penelitian ini menunjukkan bahwa perlakuan perendaman dan lama penyimpanan berpengaruh nyata terhadap nilai $\mathrm{HU}$, tetapi interaksi perlakuan tidak berpengaruh nyata terhadap nilai HU telur. Semua perlakuan perendaman dalam ekstrak daun belimbing wuluh, kecuali kontrol memiliki nilai yang tidak berbeda nyata dan berada dalam satu kolom pada uji Duncan. Hal ini menunjukkan bahwa ekstrak daun belimbing wuluh memiliki pengaruh yang baik terhadap peningkatan nilai HU telur. Sedangkan lama penyimpanan selama 0,3 , dan 4 minggu memberikan nilai HU yang lebih tinggi daripada perlakuan lainnya (Tabel. 6). Penyimpanan yang lebih lama dari 4 minggu akan menurunkan nilai HU telur. [25] Ismawati (2011) menyatakan bahwa jangka waktu telur dalam penyimpanan menjadikan telur mengalami penguapan cairan dan pelepasan gas- gas seperti karbondioksida dari isi telur, yang berakibat pada meluasnya permukaan putih telur. Selain itu, semakin lama masa penyimpanan telur membuat mikroba yang masuk melalui pori-pori kerabang semakin banyak dan dapat merusak telur.

TABEL 6. HASil UJi DUNCAN FAKTOR TUNGGAL PERLAKUAN

\begin{tabular}{|c|c|c|c|c|}
\hline \multirow{3}{*}{ No. } & \multicolumn{4}{|c|}{$\begin{array}{l}\text { Jenis Perlakuan } \\
\end{array}$} \\
\hline & \multicolumn{2}{|c|}{$\begin{array}{c}\text { Konsentrasi Ekstrak Daun } \\
\text { Belimbing }\end{array}$} & \multicolumn{2}{|c|}{ Lama Penyimpanan } \\
\hline & Konsentrasi & $\begin{array}{l}\text { Rerata } \\
\text { Nilai HU }\end{array}$ & $\begin{array}{l}\text { Waktu } \\
\text { (minggu) }\end{array}$ & $\begin{array}{l}\text { Rerata } \\
\text { Nilai HU }\end{array}$ \\
\hline 1. & $0 \%$ & $72.19 \mathbf{a}$ & 0 & 76.03 bc \\
\hline 2. & $10 \%$ & $75.11 \mathbf{b}$ & 1 & $74.38 \mathbf{a b}$ \\
\hline 3. & $15 \%$ & $75.19 \mathbf{b}$ & 2 & $73.04 \mathbf{a}$ \\
\hline 4. & $20 \%$ & $75.37 \mathbf{b}$ & 3 & $75.63 \mathbf{a b c}$ \\
\hline 5. & $25 \%$ & $75.93 \mathbf{b}$ & 4 & $77.45 \mathrm{c}$ \\
\hline 6. & $30 \%$ & $75.94 \mathbf{b}$ & 5 & $73.20 \mathbf{a}$ \\
\hline
\end{tabular}

Keterangan: Angka yang diikuti huruf yang sama tidak berbeda nyata berdasarkan uji Duncan.

\section{J. Tebal Kerabang Telur}

Tebal kerabang telur dapat menunjukkan kualitas ketahanan telur akan benturan. Benturan dapat terjadi saat pengumpulan telur dan pengiriman telur [26] Sudrajat, et al., 2014.

Hasil analisis Anova menunjukkan bahwa perlakuan perendaman, lama penyimpanan, dan interaksinya berpengaruh nyata terhadap tebal kerabang telur. Kombinasi perlakuan K5P0 (konsentrasi 30\%, penyimpanan 0 minggu) merupakan kombinasi perlakuan terbaik untuk menghasilkan kerabang telur paling tebal di antara perlakuan lainnya. Berdasarkan hasil tersebut tampak bahwa perendaman telur puyuh dalam ekstrak daun belimbing wuluh sangat bermanfaat dalam meningkatkan ketebalan kerabang telur. Menurut [27] Achmanu et al (2011), tebal kerabang telur mempunyai hubungan yang berbanding terbalik dengan suhu lingkungan, suhu yang tinggi akan mempengaruhi kualitas putih telur dan mengurangi kekuatan dan ketebalan cangkang telur.

\section{DAFTAR PUSTAKA}

[1] Abbas, M.H. (1989). Pengelolaan Produksi Unggas Jilid Ke-1. Padang: Universitas Andalas Padang.

[2] Achmanu, Muharlien, dan Salaby. (2011). Pengaruh Lantai Kandang (Rapat dan Renggang) Dan Imbangan Jantan-Betina Terhadap Konsumsi Pakan, Bobot Telur, Konversi Pakan dan Tebal Kerabang pada Burung Puyuh. Ternak Tropika. 12(1): 1-4.

[3] Argo, L.B., Trirtiarti, dan Mangisah. (2013). Kualitas Telur Ayam Arab Petelur Fase I dengan Berbagai Level Azolla microphylla. Jurnal Animal Agricultural. 2(1): 445-457.

[4] Djaelani, M.A. (2016). Kualitas Telur Ayam Ras (Gallus Sp.) Setelah Penyimpanan yang Dilakukan Pencelupan Pada Air Mendidih dan Air Kapur Sebelum Penyimpanan. Buletin Anatomi dan Fisiologi. 24(1): 122-127.

[5] Hajrawati, Johana, C., Likadja., dan Hessy. (2012). Pengaruh Lama Perendaman Sari Kulit Buah Kakao dan Lama Penyimpanan terhadap Daya Awet Telur Ayam Ras. AGRIPLUS. 22(1): 43-49.

[6] Harahap, E.U. (2007). Kajian Pengaruh Bahan Pelapis dan Teknik Pengemasan terhadap Perubahan Mutu Telur Ayam Buras Selama Transportasi dan Penyimpanan. Tesis. Bogor: Institut Pertanian Bogor.

7] Herlih. (1993). Pengaruh air perasan buah belimbing wuluh (Averrhoa bilimbi L.) terhadap kadar kolesterol serum darah tikus putih [Skripsi]. Yogyakarta: Universitas Gajah Mada.

[8] Hintono, A. (1997). Kualitas Telur yang Disimpan dalam Kemasan Atmosfer Termodifikasi. Jurnal Sainteks. 4(3): 45-51.

[9] Idris, S. (2014). Daya Simpan Telur Ayam Ras yang Diawetkan dengan Daun Belimbing Wuluh (Averrhoa bilimbi L.) Tesis. Gorontalo: Universitas Negeri Gorontalo.

[10] Ismawati, B. (2011). Bobot, Komposisi Fisik, dan Kualitas Interior Telur Puyuh (Coturnix-coturnix japonica) yang Diberi Suplemen Omega-3. Skripsi. Institut Pertanian Bogor.

[11] Joni, I., Zulfikar, dan T. Adelina. (2017). Kualitas Fisik Telur Puyuh yang Direndam dalam Larutan Gelatin Tulang Kaki Ayam dengan Lama Penyimpanan yang Berbeda. Jurnal Peternakan. Vol.14 No. 1: 31-41.

[12] Juliambarwati, M., Ratriyanto A., dan Hanifa, A. (2012). Pengaruh Penggunaan Tepung Limbah Udang dalam Ransum terhadap Kualitas Telur Itik. Sains Peternakan. 10(1): 1-6.

[13] Karmila, M. Maryati, dan Jusmawati. (2008). Pemanfaatan Daun Jambu Biji (Psidium guajava L.) sebagai Alternatif Pengawetan Telur Ayam Ras. Skripsi. Makassar: Universitas Negeri Makassar.

[14] Kurtini, T., Nova, K., dan Septinova, D. (2011). Produksi Ternak Unggas. Bandar Lampung: Universitas Lampung.

[15] Mukhlisoh, W. (2010). Pengaruh Sari Tunggal dan 
Sari Wiji Utami, Silfiatus Saadah, Fatimatuz Zuhro. Pengaruh Konsentrasi Daun Belimbing Wuluh (Averhoa Bilimbi L.) dan Lama Penyimpanan terhadap Kualitas Fisik Telur Puyuh

Gabungan Daun Belimbing Wuluh (Averrhoa bilimbi L.) terhadap Efektivitas Antibakteri Secara In Vitro. Skripsi. Malang: Universitas Islam Negeri Maulana Malik Ibrahim.

[16] Nugraha, A.B., Widayaka, K., Iriyanti, N. (2013). Penggunaan Berbagai Jenis Probiotik dalam Ransum terhadap Haugh Unit dan Volume Telur Ayam Arab. Jurnal Ilmiah Peternakan. 1(2): 606-612.

[17] Sari, M. (2009). Strategi Pemasaran Telur Puyuh pada Peternakan Puyuh Bintang Tiga (PPBT) di Situ Ilir Kecamatan Cibungbulang Kabupaten Bogor. Skripsi. Bogor: Institut Pertanian Bogor.

[18] Sudrajat, D., Kardaya, D., Dihansih, E., dan Puteri, S.F.S. (2014). Performa Produksi Telur Burung Puyuh yang Diberi Ransum Mengandung Kromium Organik. Jurnal Peternakan. 19(4): 257-262.

[19] Tugiyanti, E. dan Iriyanti, N. (2012). Kualitas Eksternal Telur Ayam Petelur yang Mendapat
Ransum dengan Penambahan Tepung Ikan Fermentasi Menggunakan Isolat Prosedur Antihistamin. Jurnal Aplikasi Teknologi Pangan. 1(2): 44-47.

[20] [USDA] United States Departement of Agriculture. (2007). Agricultural Handbook No.75: Egg Grading Manual. Washington D.C: United States Departement of Agriculture.

[21] Yamamoto, T., Juneja, L.R., Hatta, H., and Kim, M. (2007). Hen Eggs: Basic and Applied Science. Edmonton: University of Alberta.

[22] Yuwanta, T. (2010). Telur dan Kualitas Telur. Yogyakarta: Gadjah Mada University Press.

[23] Zita, L., Ledvinka, Z., dan Klesalova, L. (2013). The Effect of the Age of Japanese Quails on Certain Egg Quality Traitsand Their Relationship. Vet Arhiv. 83(1): 223-232. 